UNITED STATES

DEPARTMENT OF THE INTERIOR

GEOLOGICAL SURVEY

STREAMFLOW AND SEDIMENT TRANSPORT IN THE

QUILLAYUTE RIVER BASIN, WASHINGTON

By Leonard M. Nelson

U.S. GEOLOGICAL SURVEY

OPEN-FILE REPORT 82-627

Prepared in cooperation with the

Quileute Tribal Council and the

U.S. Army Corps of Engineers, Pacific

Northwest Division, Seattle District

Tacoma, Washington

1982 
UNITED STATES DEPARTMENT OF THE INTERIOR

JAMES G. WATT, Secretary

GEOLOGICAL SURVEY

Dallas L. Peck, Director

For additional information write to:

U.S. Geological Survey, WRD

1201 Pacific Avenue - Suite 600

Tacoma, Washington 98402-4384 
Abstract-1-1-1

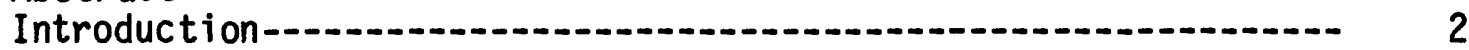

Description of the basin-........................................ 3

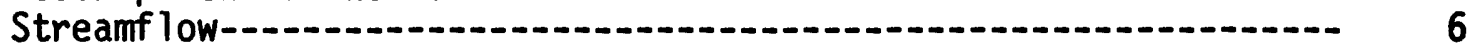

Low flows -

Flood discharges-................................................... 15

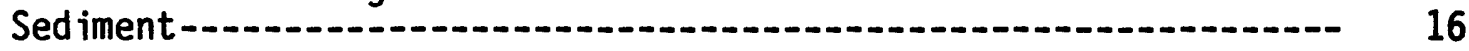

Suspended-sed iment transport-_.................................... 17

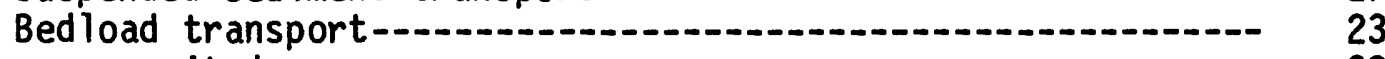

References cited-1..-...- 28

\section{ILLUSTRATIONS}

FIGURE 1. Map showing mean annual precipitation in the

Quillayute River basin, during period 1930-57-...-.- 4

2. Profiles of Quillayute River and selected tributaries-...-...-. 5

3. Graph showing mean monthly precipitaton at Forks----- 6

4. Map showing data-collection sites in the Quillayute

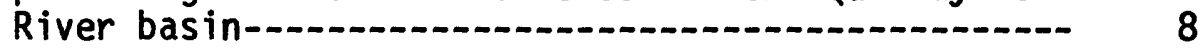

5. Graph showing annual mean discharges at two gaging stations in the Quillayute River basin-........-.- 9

6. Graph showing flow-duration curves for five gaging stations in the Quillayute River basin-...-...-.- 13

7-10. Graphs showing relation of instantaneous suspendedsediment concentration to concurrent water discharge for:

7. Bogachiel River near LaPush-_-_-_-_-_-_-.-. 19

8. Calawah River near Forks-................-. 20

9. Soleduck River near Quillayute-.....-.....-. 21

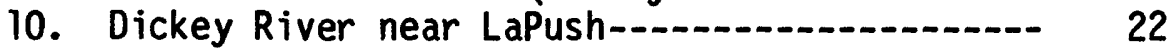

11. Graph showing relation of suspended-sediment discharge to bedload for White River below Clearwater River, near Buckley, during 1974-76. Values for the Soleduck and Bogachiel Rivers on Feb. 9 and Dec. 14, 1979, are plotted-_........................... 


\section{TABLES}

Page

TABLE 1. Data-collection sites in the Quillayute River basin-.. 7

2. Mean, maximum, and minimum monthly, and mean annual stream discharges at six gaging stations in the Quillayute River basin-...........................................

3. Preferred discharges for stee thead and saimon spawning and rearing at selected sites in the Quillayute River basin-.......................-..- 12

4. Low-flow-frequency data for streamflow stations with with 10 or more years of data-..................... 14

5. Estimated 7-day-low flows for selected sites in the the Quillayute River basin, based on measurements made October 1976 through September 1978-

6. Suspended-sediment data at selected sites, Quillayute River basin-

7. Particle-size data from selected sites, Quillayute

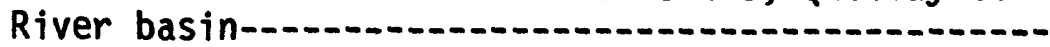

METRIC CONVERSION FACTORS

\section{Multiply}

inches (in.)

feet $(\mathrm{ft})$

cubic feet $\left(\mathrm{ft}^{3}\right)$

miles (mi)

square miles ( $\mathrm{mi} \mathbf{2}^{2}$

tons $(2,000$ lbs $)$
By

2.54

0.3048

0.02832

1.609

2.590

0.9072
To obtain

centimeters (cm) meters (m) cubic meters $\left(\mathrm{m}^{3}\right)$ meters (m) square kilometers $\left(\mathrm{km}^{2}\right)$ tonnes

National Geodetic Vertical Datum of 1929 (W6VD of 1929): A geodetic datum derived from a general adjustment of the first-order level nets of both the United States and Canada, formerly called "Mean Sea Level." NGVO of 1929 is referred to as sea level in this report. 


\title{
STREAMFLOW AND SEDIMENT TRANSPORT IN \\ THE QUILLAYUTE RIVER BASIN, WASHINGTON
}

By Leonard M. Nelson

\begin{abstract}
From October 1976 to September 1978 the U.S. Geological Survey made a reconnaissance evaluation of the fluvial-sediment transport and documented the natural streamflow characteristics in the Quillayute River basin in northwestern Washington.

Most of the flow of the Quillayute River originates from three tributary streams; the Soleduck, Bogachiel, and Calawah Rivers. Flow in the summer months from the Calawah River is about half that from either the Bogachiel or Soleduck Rivers. In the winter months flow from the Soleduck River is about $1 \frac{1}{2}$ times that of the Bogachiel or Calawah Rivers. In general, the highest monthly flows during the winter are about 10 times greater than the lowest monthly flows during the summer except for the Dickey River, where winter flows are about 20 times greater. Annual mean discharges may vary greatly from year to year, ranging from about $1 / 2$ to $1 / 2$ times the mean annual discharge.

For the study period, the observed suspended-sediment concentration ranged from less than 1 to 2,150 milligrams per liter. The estimated mean annual suspended-sediment discharges were: Bogachiel River $-400,000$ tons (includes Calawah River); Calawah River-120,000 tons; Soleduck River-120,000 tons; Dickey River-75,000 tons; and other tributaries--10,000 tons; for a total of 605,000 tons transported annually by the Quillayute River. The estimated annual bedload of 21,000 tons was transported into the Quillayute River by the Soleduck, Bogachiel, and Dickey Rivers.
\end{abstract}




\section{INTRODUCTION}

From October 1976 to September 1978 the U.S. Geological Survey made a reconnaissance evaluation of the fluvial-sediment transport and documented the natural streamflow characteristics in the Quillayute River basin in northwestern Washington. The purpose of this investigation was to provide an assessment of the streamflow, water-quality, and sediment characteristics of the major tributaries of the Quillayute River. The water-quality characteristics of the rivers will be described by in a report by $M$. $O$. Fretwell. This report describes the streamflow and sediment-transport characteristics of the rivers.

The study of streamflow and suspended-sediment transport was made in cooperation with the Quileute Tribal Council. The U.S. Army Corps of Engineers, Seattle District, supported the study of bedload transported into the Quillayute River.

To determine the proportions of streamflow from the major tributaries of the Quillayute River, daily discharge records from six gaging stations were analyzed, one each on the Bogachiel and Calawah Rivers, and two on the Soleduck and Dickey Rivers. Fifty-eight discharge measurements were obtained at six miscellaneous sites, one on the Bogachiel, three on the Calawah, and two on the Dickey River, during low flows, May-September 1976. The miscellaneous site on the East Fork of the Dickey River (site 15) is at the location of a discontinued gaging station.

Suspended-sediment samples for this study were obtained periodically at four sites, one each on the Bogachiel, Calawah, Soleduck, and Dickey Rivers. The relation of suspended-sediment concentration to streamflow (water discharge) during the study was evaluated mostly from data obtained at these four sites. The Helley-Smith sampler was used to obtain bedload data near the mouths of the Dickey, Soleduck, and Bogachiel Rivers.

The methods used for obtaining and analyzing suspended-sediment samples collected during this study are described by Guy and Norman (1970) and Guy (1969). The limited range and number of sediment data obtained during this reconnaissance study required the use of extrapolation and interpolation. 


\section{DESCRIPTION OF THE BASIN}

The Quillayute River basin covers an area of 629 square miles, of which 93 percent is in Clallam County and 7 percent in Jefferson County. The Quileute Indian Reservation, about 1,000 acres, lies at the mouth of the Quillayute River. The headwaters of the Quillayute River tributaries originate on the western slope of the Olympic Mountains, 33 miles east of Forks (fig. 1). The large tributaries, Soleduck, Bogachiel, and Calawah Rivers, flow westerly down steep slopes (fig. 2) from the mountains to the coastal terraces. These terraces, where all streams have similar low gradient, extend upstream for about 30 river miles from the mouth of the Quillayute River. On the terraces the Calawah River flows into the Bogachiel, and the Bogachiel and Soleduck Rivers converge to form the Quillayute River about 6 miles east of La Push. Another large tributary, the Dickey River, drains the northwest part of the Quillayute River basin and heads largely on the coastal terraces. Most of these streams are used by salmon and steelhead for migration, spawning, and rearing. These fish are an important resource for the Quileute Indians and to the commercial and sport fishery of the State.

Originally, the basin was heavily forested with conifers, except for some small areas of marshes and open prairies. Douglas fir grow on the gravel terraces along the large rivers, but the dominant tree elsewhere is the western hemlock. Sitka spruce and western redcedar are found in swamps and bottomlands. Cutover areas are in various stages of reforestation and are covered with regrowth conifers and deciduous trees. Shrubby undergrowth and ferns are prevalent, and the undergrowth is thicker at lower elevations.

The terrain in the Quillayute River basin has been described as largely rough broken and rough mountainous land, but with no identification of soil type (Smith and others, 1951). This description gives little indication of the erodibility of the soils. The mountains are generally bedrock covered by thin soils, and most of the coastal terraces are covered by shallow and stony soils (Huntting and others, 1961).

The principal industry in the basin is logging. Logging practices are controlled largely by land ownership; that is, logging is not permitted in the Olympic National Park and is controlled by the U.S. Forest Service on Olympic National Forest lands. The land ownership in the Quillayute River basin is given in the following table.

\begin{tabular}{|c|c|c|c|}
\hline \multirow[b]{2}{*}{ Drainage area } & \multicolumn{3}{|c|}{$\begin{array}{l}\text { Land Ownership } \\
\text { (approximate square miles) }\end{array}$} \\
\hline & $\begin{array}{l}\text { Olympic } \\
\text { National } \\
\text { Forest }\end{array}$ & $\begin{array}{l}\text { Olymple } \\
\text { National } \\
\text { Park }\end{array}$ & $\begin{array}{l}\text { Non- } \\
\text { Federal }\end{array}$ \\
\hline Bogachiel River & 8 & 82 & 21 \\
\hline $\begin{array}{l}\text { Bogachiel River } \\
\text { Calawah River (tributary } \\
\text { to Bogachiel) }\end{array}$ & $\begin{array}{l}84 \\
76\end{array}$ & $\begin{array}{r}109 \\
27\end{array}$ & $\begin{array}{l}94 \\
30\end{array}$ \\
\hline $\begin{array}{l}\text { Soleduck River } \\
\text { Dickey River }\end{array}$ & $\begin{array}{r}72 \\
0\end{array}$ & $\begin{array}{r}73 \\
0\end{array}$ & $\begin{array}{r}81 \\
108\end{array}$ \\
\hline $\begin{array}{l}\text { Small streams (tributary } \\
\text { to Quillayute) }\end{array}$ & 0 & 3 & 5 \\
\hline Quillayute River & 156 & 185 & 288 \\
\hline
\end{tabular}




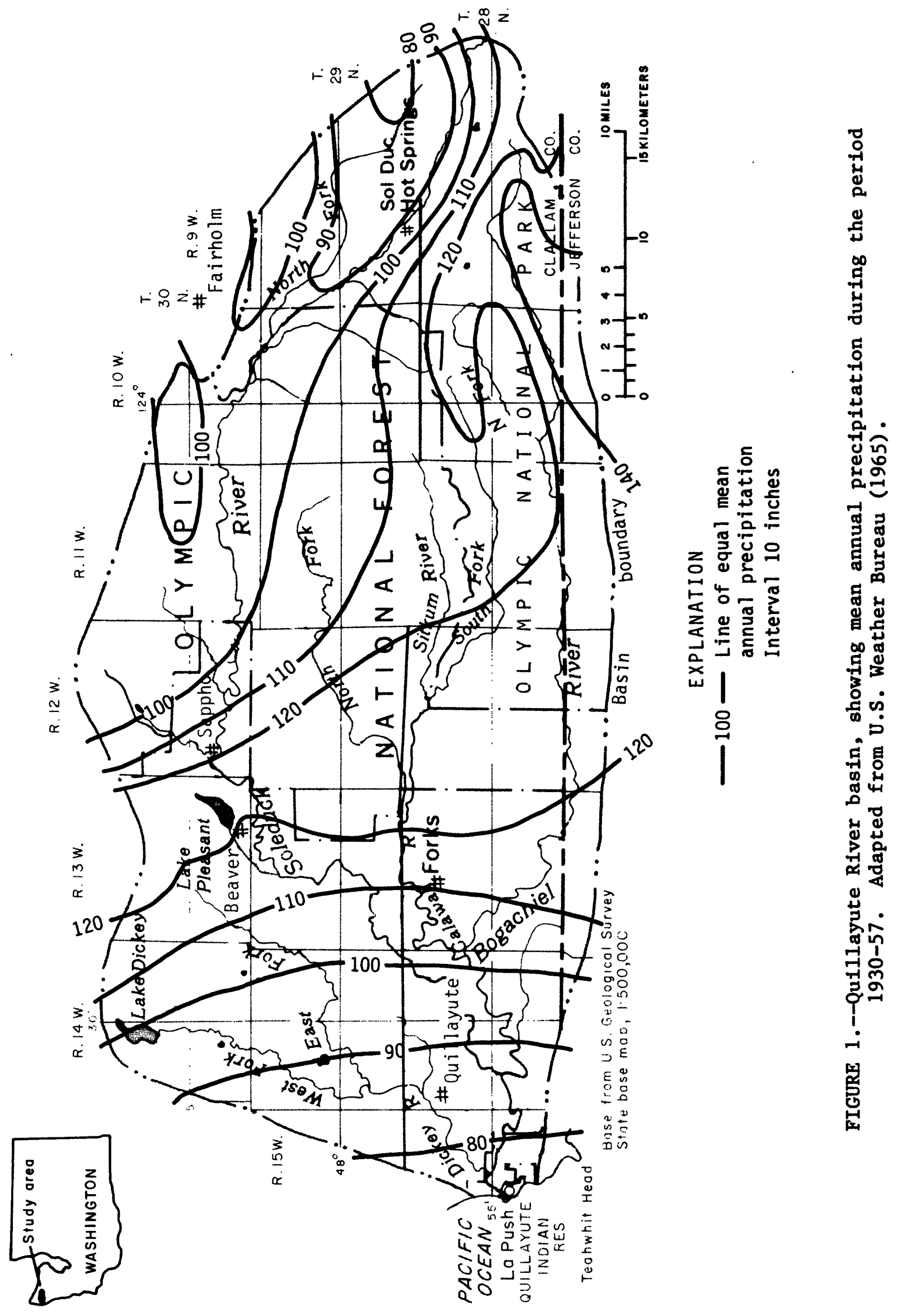




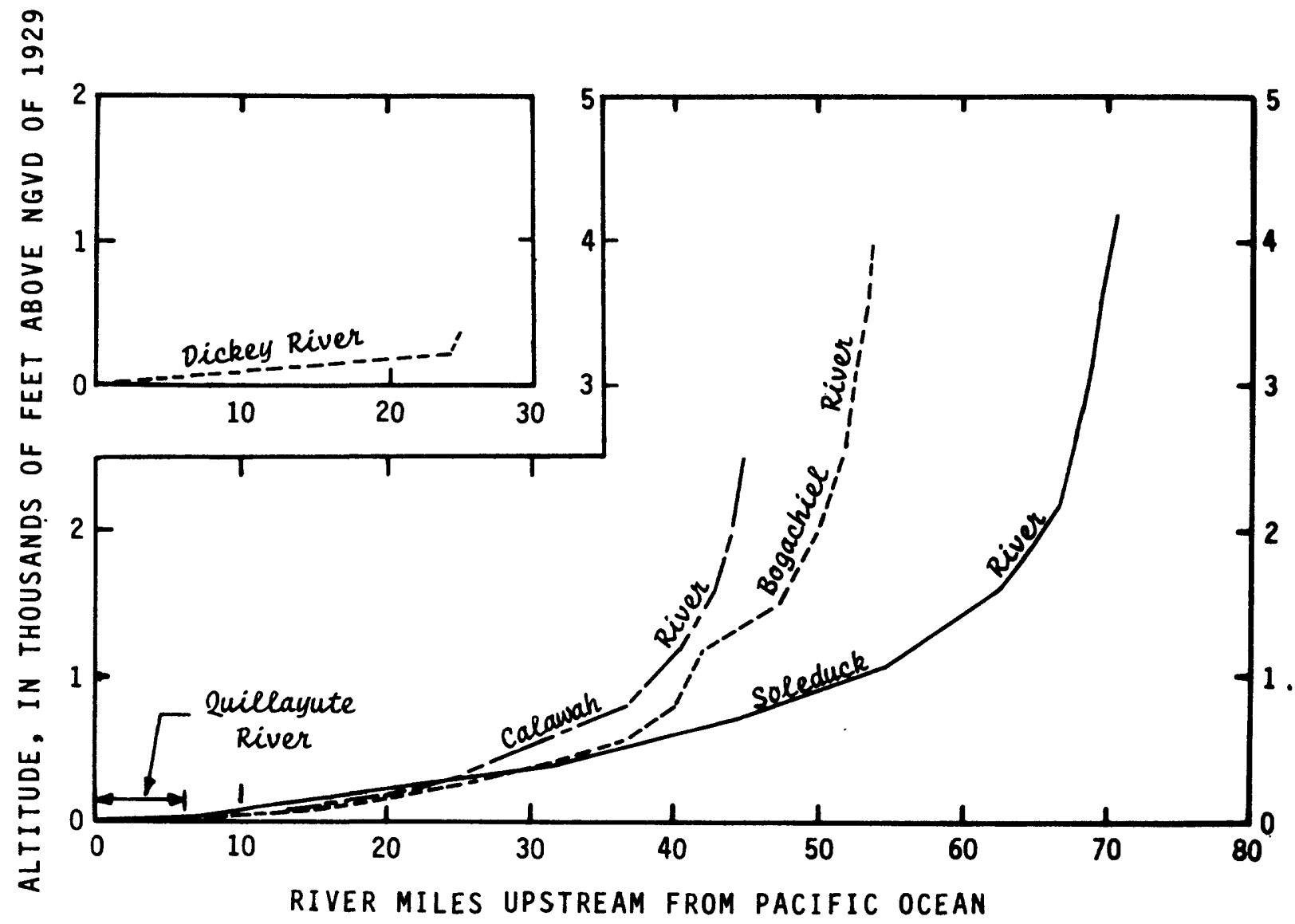

FIGURE 2.--Profiles of Quillayute River and selected tributaries. 


\section{STREAMFLOW}

Throughout the Quillayute River basin, streamflow is not artificially stored or diverted and, except for snowmelt in the higher elevations, is primarily influenced by rainstorms. The precipitation in the basin (fig. 1) ranges from 75 to 145 inches annually (U.S. Weather Bureau, 1965). Precipitation is highest in December and lowest in July and August (fig. 3).

Streamflow closely follows the precipitation, generally increasing gradually above base flow with fall and winter rains during September to December or January, decreasing gradually with less frequent storms during February to May, and continuing to decrease as it is sustained by ground-water discharge from June to early September.

The runoff pattern in the higher elevations of the Soleduck and Bogachiel River basins is influenced by the storage of precipitation as snow. There, the streamflow generally (1) increases in October-December due to heavy rain, (2) decreases during January-March as precipitation falls largely as snow, (3) increases gradually as the snow melts during April-June, and (4) decreases during July-September.

Streamflow records have been published for seven gaging and three crest-stage stations and six additional miscellaneous sites in the basin (table 1 , fig. 4) by the U.S. Geological Survey (1955, 1964, 1971-79). Discharge measurements made at discontinued gaging stations are published as measurements at miscellaneous sites.

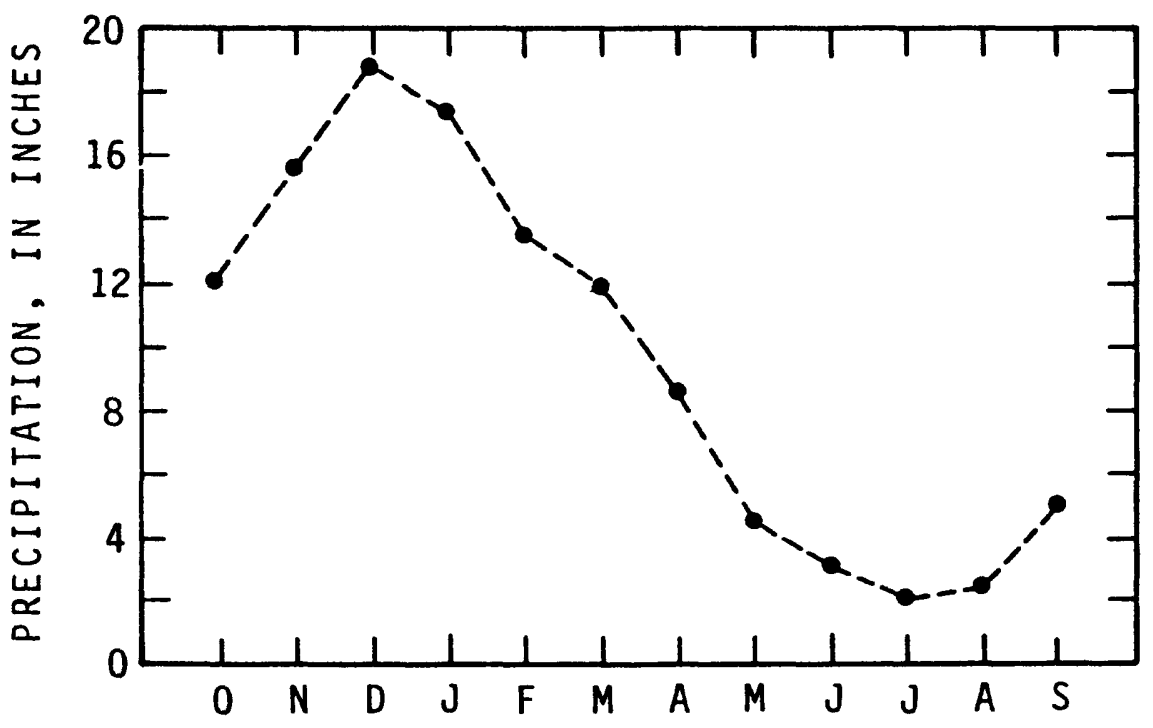

FIGURE 3.--Mean monthly precipitation at Forks. 


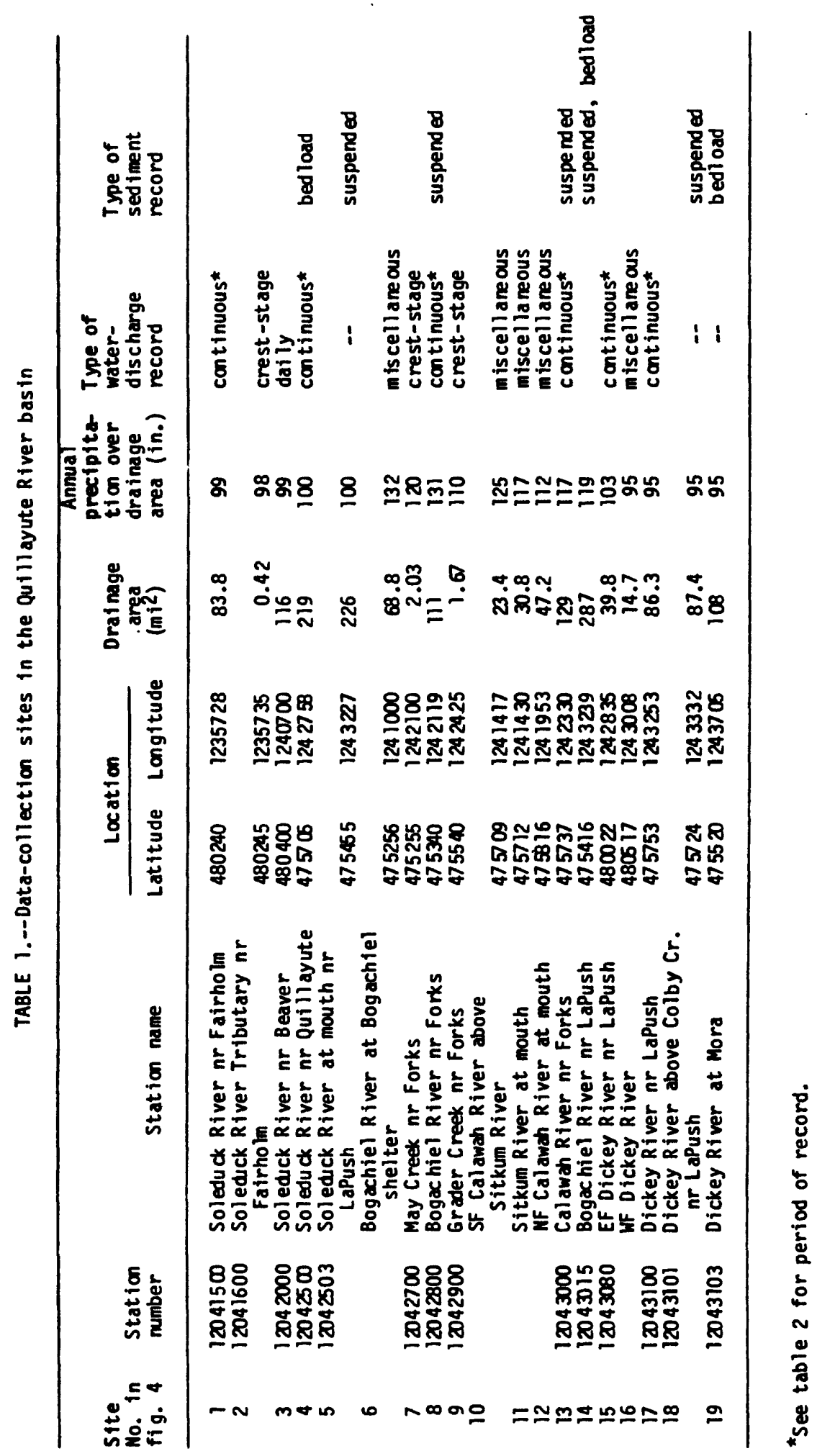




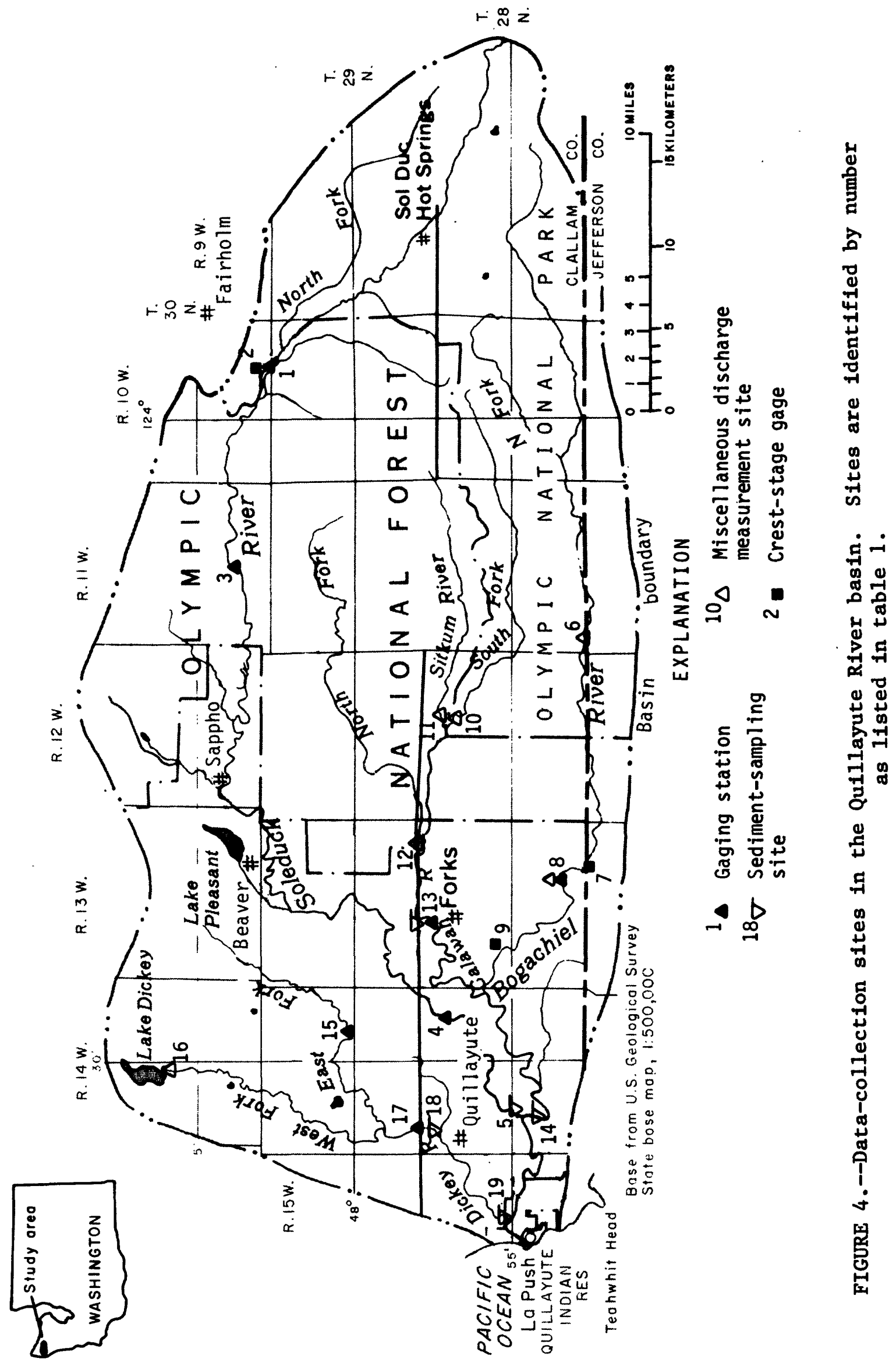


The characteristics of streamflow at continuous gaging stations can be described by: (1) mean monthly discharges; (2) mean annual discharges; (3) daily discharges from flow-duration curves; (4) low flows; and (5) peak discharges. The mean monthly and mean annual discharges at six gaging stations in the basin are given in table 2. The values in this table show that most of the flow in the Quillayute River originates from the Soleduck, Bogachiel, and Calawah Rivers. Flow in the summer months from the Calawah River is about half that from either the Soleduck or Bogachiel Rivers. In the winter months flow from the Soleduck River is about $11 / 2$ times that of the Bogachiel and Calawah Rivers. In general, the highest monthly flows occurring during the winter are about 10 times greater than the lowest monthly flows occurring during the summer except for the Dickey River, where winter flows are about 20 times greater. Maximum monthly flows range from about $1 \%$ to $2 \frac{1}{2}$ times greater than the mean monthly flows for most months. Minimum monthly flows range from about $1 / 3$ to $2 / 3$ times the mean monthly flows in the winter months and from 1/4 to 3/4 times the mean monthly flows in the summer months.

Annual mean discharges may vary greatly from year to year, ranging from about $1 / 2$ to $1 / 2$ times the mean annual discharge for a gaging station, as is shown for two stations in figure 5. The two stations in figure 5 represent drainage basins approximately equal in size, the Dickey River being slightly greater. However, the annual mean discharge for the Dickey River is somewhat less than for the Soleduck River, indicating less runoff from the lowland stream.

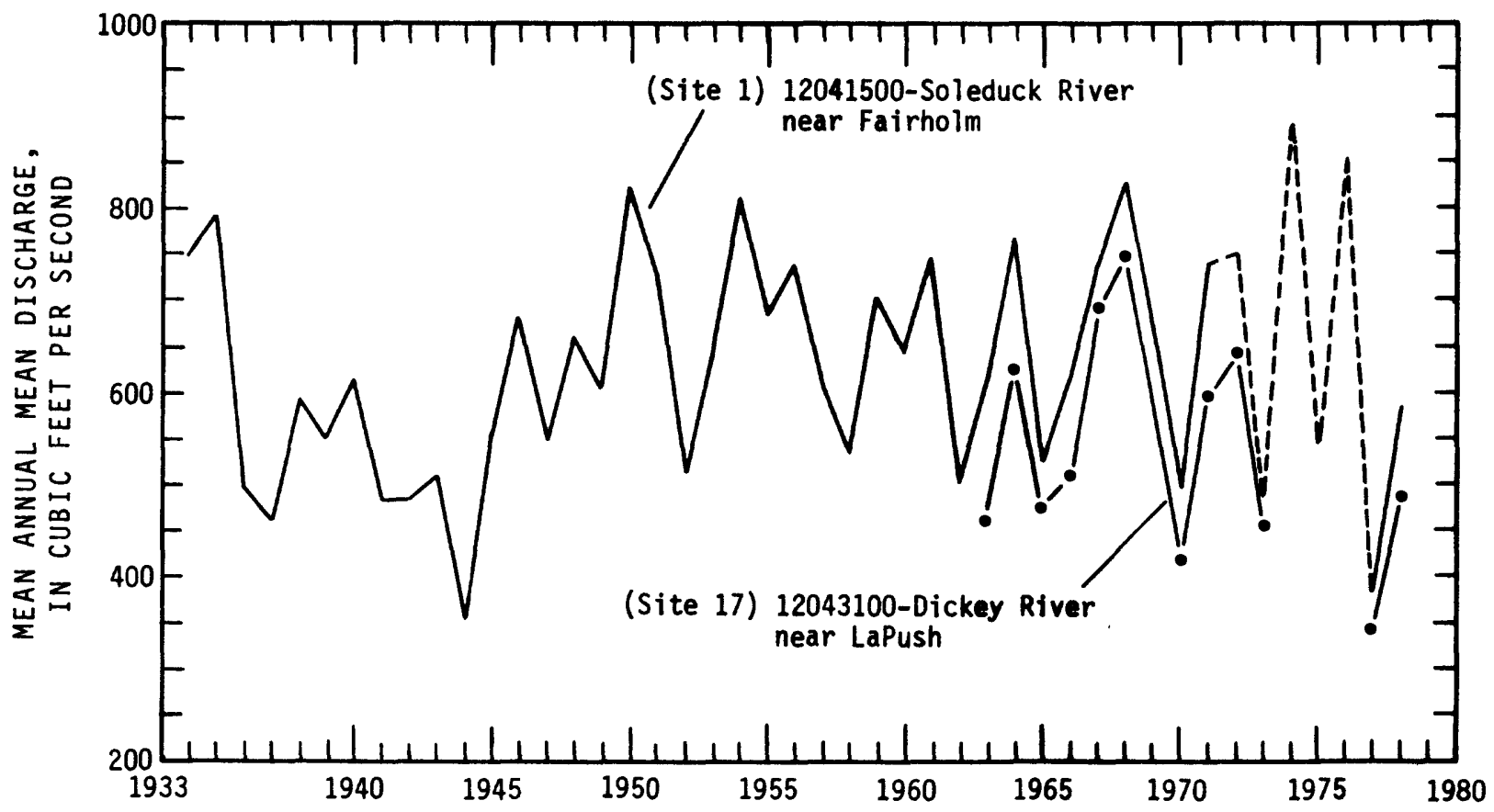

FIGURE 5.--Annual mean discharges at two gaging stations in the Quillayute River basin. 


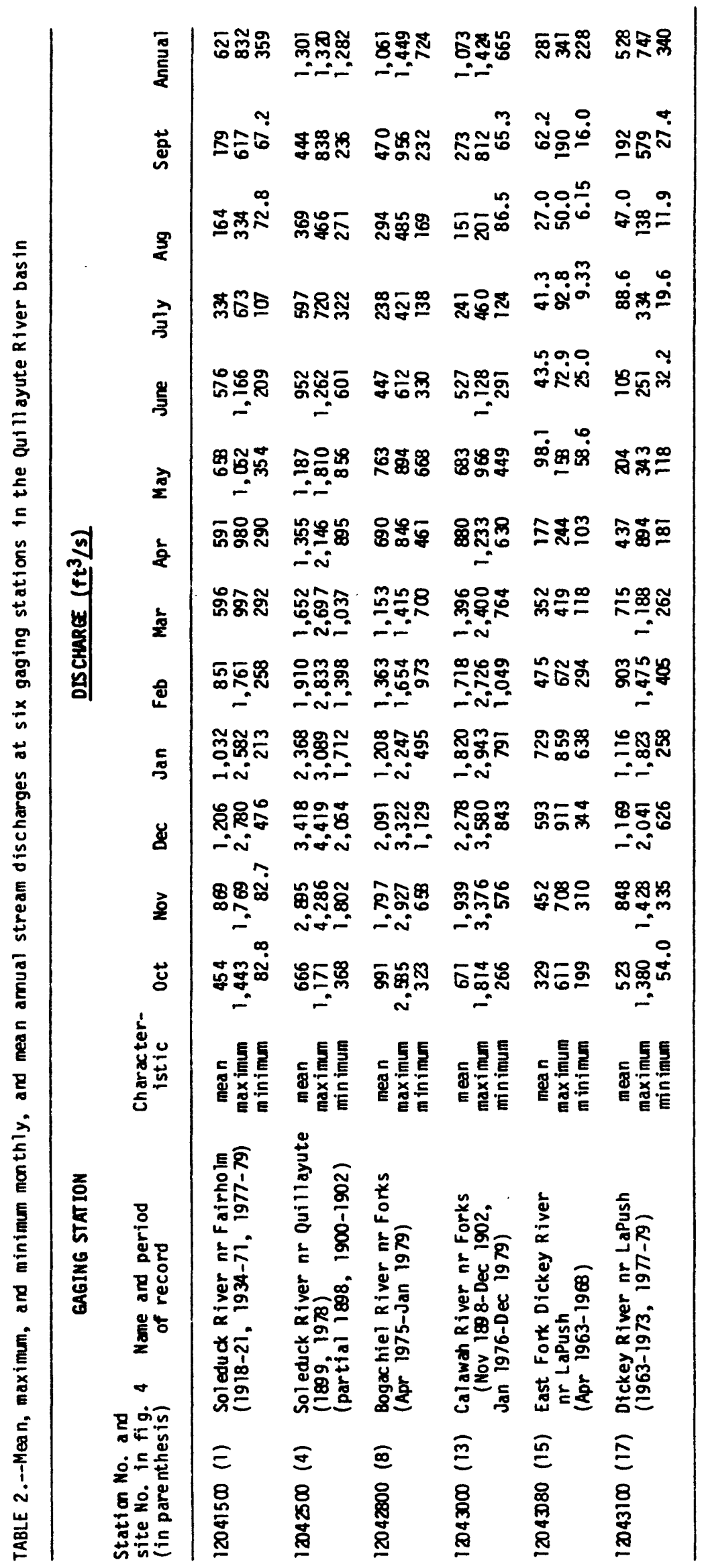


In the Quillayute River basin one of the major uses of the streams is for fish propagation. The stream discharges preferred by salmon and steelhead trout depend on a number of habitat factors, among them water depth, velocity, and quality, suitable streambed materials, shade and shelter, and sources of food. The discharges preferred only on the basis of water depth and velocity criteria for spawning and rearing have been studied by Swift (1976, 1979), and estimates of those preferred discharges can be made for any site where either channel width or drainage area can be determined. Preferred discharges have been estimated for 11 sites in the basin using drainage area (table 3). Comparison of the values in table 3 with those in table 2 for the amounts of water available indicates that, in general, streamflow in the basin is adequate for spawning in the autumn and winter months, but may be somewhat deficient for rearing in some summer months.

Flow-duration curves portray the range of streamflow and indicate the percentage of time that any daily discharge was equaled or exceeded. Flow-duration curves for the five gaging stations in the Quillayute River basin having sufficient records of water discharge to determine the curves are shown in figure 6 . Note that the Dickey River, which drains mostly the coastal lowlands, has a greater range of flow than the rivers draining the mountainous areas. Snowmelt during the summer helps to sustain the flow of the Soleduck and Bogachiel Rivers, and the summer flow of the Dickey River is maintained primarily by ground water.

\section{Low Flows}

Information on the magnitude, frequency, and duration of low flows is useful for comparing the streamflow available with the streamflow required to meet the needs of fish and other uses during the low-flow season. This information may be obtained from low-flow-frequency curves, which can be prepared from past streamflow records greater than 10 years in length. Average minimum discharges for durations of $7,30,60,90$, and 183 consecutive days at selected frequencies were determined (Riggs, 1972) for Soleduck River near Fairholm and Dickey River near La Push (table 4), which are the only two gaging stations with 10 or more years of record in the basin.

Discharge measurements during low flows were obtained at six partial-record sites and four short-term gaging stations in the basin during the study period to allow estimates of low-flow discharges to be made at those locations. These measurements were then correlated with concurrent discharges at the two long-term gaging stations to obtain estimates of the 7-day low flows for a 50-percent probability of not being equaled or exceeded in any year at the short-term and partial-record sites (table 5). 
TABLE 3.--Preferred discharges for steelhead and salmon spaming and rearing at selected sites in the Quillayute River basin 1

\begin{tabular}{|c|c|c|c|c|c|}
\hline \multirow[b]{2}{*}{$\begin{array}{l}\text { Site No. } \\
\text { in fig. } 4\end{array}$} & \multirow[b]{2}{*}{$\begin{array}{l}\text { Name of streamf low station or site } \\
\text { (USES station number in parenthesis) }\end{array}$} & \multicolumn{3}{|c|}{ Preferred discharge $\left(\mathrm{ft}^{3} / \mathrm{s}\right)$ for: } & \multirow[b]{2}{*}{$\begin{array}{l}\text { Sockeye and } \\
\text { Coho salmon } \\
\text { spawning }\end{array}$} \\
\hline & & $\begin{array}{l}\text { Salmon } \\
\text { rearing }\end{array}$ & $\begin{array}{l}\text { Stee lhead } \\
\text { spawning }\end{array}$ & $\begin{array}{l}\text { Chinook, Prink, } \\
\text { and Chum saimon } \\
\text { spawning }\end{array}$ & \\
\hline 1 & $\begin{array}{l}\text { So leduck River nr Fairho lm } \\
(12041500)\end{array}$ & 86 & 320 & 350 & 190 \\
\hline 4 & $\begin{array}{l}\text { So leduck River nr Quillayute } \\
(12042500)\end{array}$ & 180 & 610 & 680 & 400 \\
\hline 6 & Bogachiel River at Bogachiel shelter & 74 & 280 & 300 & 170 \\
\hline 8 & $\begin{array}{l}\text { Bogachiel River nr Forks } \\
(12042800)\end{array}$ & 110 & 390 & 430 & 240 \\
\hline 10 & SF Calawah River above Sitkum River & 32 & 140 & 140 & 74 \\
\hline 11 & Sitkum River at mouth & 39 & 160 & 170 & 90 \\
\hline 12 & NF Calawah River at mouth & 55 & 220 & 230 & 120 \\
\hline 13 & $\begin{array}{l}\text { Calawah River nr Forks } \\
(12043000)\end{array}$ & 120 & 430 & 470 & 270 \\
\hline 15 & $\begin{array}{l}\text { EF Dickey River nr La Push } \\
(12043080)\end{array}$ & 48 & 200 & 210 & 110 \\
\hline 16 & W.F. Dickey River & 22 & 100 & 100 & 52 \\
\hline 17 & $\begin{array}{l}\text { Dickey River nr La Push } \\
(12043100)\end{array}$ & 88 & 330 & 360 & 200 \\
\hline
\end{tabular}

1 Discharges are based on drainage areas applied in equations given by Swift $(1976,1979)$. 


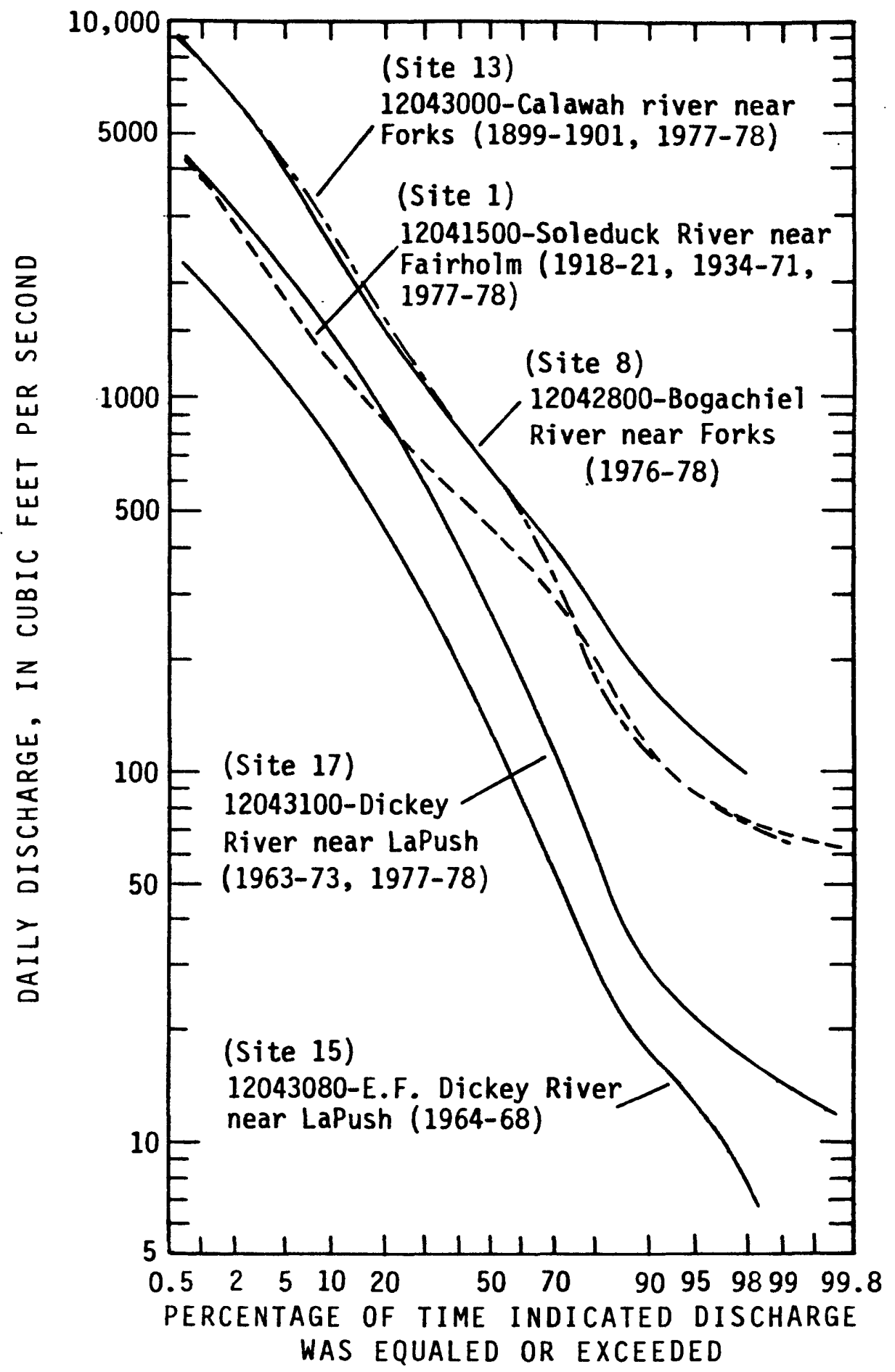

FIGURE 6.--Flow-duration curves for five gaging stations in the Quillayute River basin. 
TABLE 4.--Low-f low-frequency data for streamf low stations with 10 or more years of data

\begin{tabular}{|c|c|c|c|c|c|c|}
\hline $\begin{array}{l}\text { Site } \\
\text { No. in } \\
\text { fig. } 4\end{array}$ & $\begin{array}{l}\text { Station name and } \\
\text { USGS number, and } \\
\text { period of record }\end{array}$ & $\begin{array}{l}\text { Number of } \\
\text { consecutive } \\
\text { days }\end{array}$ & \multicolumn{4}{|c|}{$\begin{array}{l}\text { Streamflow }\left(\mathrm{ft}^{3} / \mathrm{s}\right) \text { for ind icated } \\
\text { percent probabilities of being } \\
\text { not equaled or exceeded }\end{array}$} \\
\hline 1 & $\begin{array}{l}\text { Sol edick River nr Fairholm } \\
12041500 \\
(1918-21,1934-72,1976-79)\end{array}$ & $\begin{array}{r}7 \\
30 \\
60 \\
90 \\
183\end{array}$ & $\begin{array}{r}79 \\
96 \\
102 \\
158 \\
319\end{array}$ & $\begin{array}{r}66 \\
78 \\
92 \\
115 \\
256\end{array}$ & $\begin{array}{r}62 \\
71 \\
81 \\
98 \\
231\end{array}$ & $\begin{array}{r}58 \\
68 \\
74 \\
86 \\
213\end{array}$ \\
\hline 17 & $\begin{array}{l}\text { Oickey River nr La Push } \\
1043100 \\
(1963-74,197-79)\end{array}$ & $\begin{array}{r}7 \\
30 \\
60 \\
90 \\
183\end{array}$ & $\begin{array}{r}18 \\
24 \\
37 \\
59 \\
139\end{array}$ & $\begin{array}{r}13 \\
17 \\
24 \\
36 \\
109\end{array}$ & $\begin{array}{l}12 \\
15 \\
19 \\
28 \\
97\end{array}$ & $\begin{array}{l}11 \\
13 \\
16 \\
22 \\
89\end{array}$ \\
\hline
\end{tabular}

TABLE 5. - Est imated 7-day-low flows for selected sites in the Quillayute River basin, based on masurements made October 1976 through September 1978

\begin{tabular}{|c|c|c|}
\hline $\begin{array}{l}\text { Site } \\
\text { No. In } \\
\text { fig. } 4 \\
\end{array}$ & $\begin{array}{l}\text { Nane of stream or streamf low station } \\
\text { (USES st ation number in parenthes is) }\end{array}$ & $\begin{array}{l}\text { Magnitude }\left(\mathrm{ft}^{3} / \mathrm{s}\right) \text { of } 7 \text {-day } \\
\text { low flow having a } 50 \text {-percen } \\
\text { probabtlity of being not } \\
\text { equaled or exceeded }\end{array}$ \\
\hline 4 & $\begin{array}{l}\text { Soleduck River nr Quill ayute } \\
(1242500)\end{array}$ & 279 \\
\hline 6 & Bogachiel River at Bogachiel Shelter & 74 \\
\hline 8 & $\begin{array}{l}\text { Bogachiel River nr Forks } \\
(12042800)\end{array}$ & 119 \\
\hline 10 & $\begin{array}{l}\text { South Fork Calawah River upstream } \\
\text { of Sitkum River }\end{array}$ & 15 \\
\hline 11 & Sitkum River above mouth & 15 \\
\hline 12 & North Fork Calawah above mouth & 22 \\
\hline 13 & $\begin{array}{l}\text { Calawah River nr Forks } \\
(12043000)\end{array}$ & 80 \\
\hline 15 & $\begin{array}{l}\text { East Fork Dickey River nr LaPush } \\
(12043080)\end{array}$ & 9.2 \\
\hline 16 & West Fork Dickey River & 3.3 \\
\hline
\end{tabular}




\section{Flood Discharges}

Hydrologic analyses were carried out to establish the peak discharge for floods of selected frequencies at gaging stations on streams throughout Clallam County, following the guidelines set by the U.S. Water Resources Council (1976). The flood discharges for the gaging stations have been related to basin characteristics (drainage area and precipitation) to provide a means of estimating flood-discharge characteristics (10-, 50-, and 100-year peak discharges) at the mouths of the rivers in the basin. The values so determined are as follows:

\begin{tabular}{lcccr}
\hline & \multicolumn{3}{c}{ Flood discharge $\left(\mathrm{ft}^{3} / \mathrm{s}\right)$} \\
\cline { 2 - 3 } \multicolumn{1}{c}{ Stream } & 10-year & & 50 -year & 100-year \\
\cline { 2 - 3 } \cline { 5 - 5 } Soleduck River & 28,900 & & 39,700 & 45,100 \\
Calawah River & 20,600 & & 28,000 & 31,600 \\
Bogach fel River & 42,200 & & 56,600 & 63,600 \\
Dickey River & 14,300 & & 20,000 & 22,800 \\
Quillayute River & 78,900 & 106,000 & 119,000 \\
\hline
\end{tabular}

Many lowlands along the streams are flooded each year. The extent of flooding for many stream reaches in the Quillayute River basin is shown on flood-boundary maps (U.S. Department of Housing and Urban Development, 1980). 


\section{SEDIMENT}

Most of the sediment transported in the basin is eroded from thin soils by intense rainfall. Much of this sediment moves into the channels by sheet erosion, and in some channels sediments are eroded from the bed and banks during high streamflow. The suspended sediment includes clay, silt, and sand particles, but the bedload is composed largely of sand, gravel, and cobbles.

Suspended-sediment samples were collected periodically at four sites in the Quillayute River basin (sites 5, 13, 14, and 18; shown in fig. 4). Data from these samples are published by the U.S. Geological Survey (1978). Miscellaneous suspended-sediment samples were collected from the Bogachiel River near Forks (site 8). Regression analysis was used to compute the relation between instantaneous suspended-sediment concentration and concurrent water discharge for these five sites. This relation was used in the manner described by Colby (1956) to estimate the suspended-sediment transport.

Estimating the mean annual sediment yield of streams in the study area from reconnaissance data collected during the 2-year study period required the assumption that the computed relation between suspended-sediment transport and streamflow for the short period is the same as that for the longer period for which streamflow records are available. Using the method described by Nelson (1970) to estimate the mean annual sediment yields, historic streamflow records were analyzed and a relation for each of the five sites was established between the parameter $k_{n}$ (annual peak water discharge times annual mean water discharge times $10^{-6}$ ) and the annual suspended-sediment discharge, estimated from the data collected during the period 1976-78. Values of $k_{n}$ were obtained for each year of streamflow record for each site and used to estimate suspended-sediment discharge for each year. These annual suspended-sediment discharges were averaged to obtain the estimated mean annual suspended-sediment discharge. 


\section{Suspended-Sediment Transport}

Suspended-sediment transport in the Quillayute River basin changes rapidly, and the annual suspended-sediment discharge is highly dependent upon the occurrence of high streamflow periods. The available descriptions of the geology and soils in the basin are too generalized to provide insight to the source of the sediment being transported.

The sediment data obtained during this study document existing conditions and do not define the effect of land use on suspended-sediment transport in the basin. In the upper Bogachiel River, where most of the drainage basin is in the Olympic National Park and little timber is harvested (National Forest Service, written commun., 1978), suspended-sediment yield (table 6) is greater than in the Calawah River drainage, with large timber harvest.

Runoff quantity and stream gradient have the greatest effect upon the amount of suspended sediment transported. The Bogachiel River has greater precipitation and runoff per square mile, a steep gradient, less stable channels than Soleduck and Calawah Rivers, and transports more sediment than the other major tributaries. The Dickey River, which has the lowest gradient and low precipitation and runoff, transports less sediment than the Calawah, Soleduck, and Bogachiel Rivers.

Observed suspended-sediment concentrations ranged from less than 1 to $2,150 \mathrm{mg} / \mathrm{L}$ during the study and were usually less than $10 \mathrm{mg} / \mathrm{L}$. Thus, the streams appeared clear most of the time.

The relation between instantaneous suspended-sediment concentration and concurrent water discharge was determined for the Bogachiel, Calawah, Soleduck, and Dickey Rivers (figs. 7- 10). These relations and streamflow records used to estimate suspended-sediment discharges for 1977 and 1978 are given in table 6 .

The wide variation in suspended-sediment concentration for any given stream discharge (figs. 7-10) indicates a probable rapid change in sediment discharge and differences in sediment concentration during the rising and falling stages of a freshet. The annual suspended-sediment discharge can vary considerably from year to year, as indicated by the record for the Dickey River, which transported an estimated 13,000 tons in 1977 and 37,000 tons in 1978 and an estimated mean annual discharge of 60,000 tons (table 6). A mean annual discharge of 15,000 tons was estimated for the Dickey River downstream from site 18, and 10,000 tons was estimated for the small drainages to the Quillayute River downstream of the confluence of the Soleduck and Bogachiel Rivers. In both 1977 and 1978, about 90 percent of annual suspended-sediment discharge from the Calawah River occurred during 5 percent of the days when high flows occurred, typical of findings for most streams in the Quillayute River basin. 


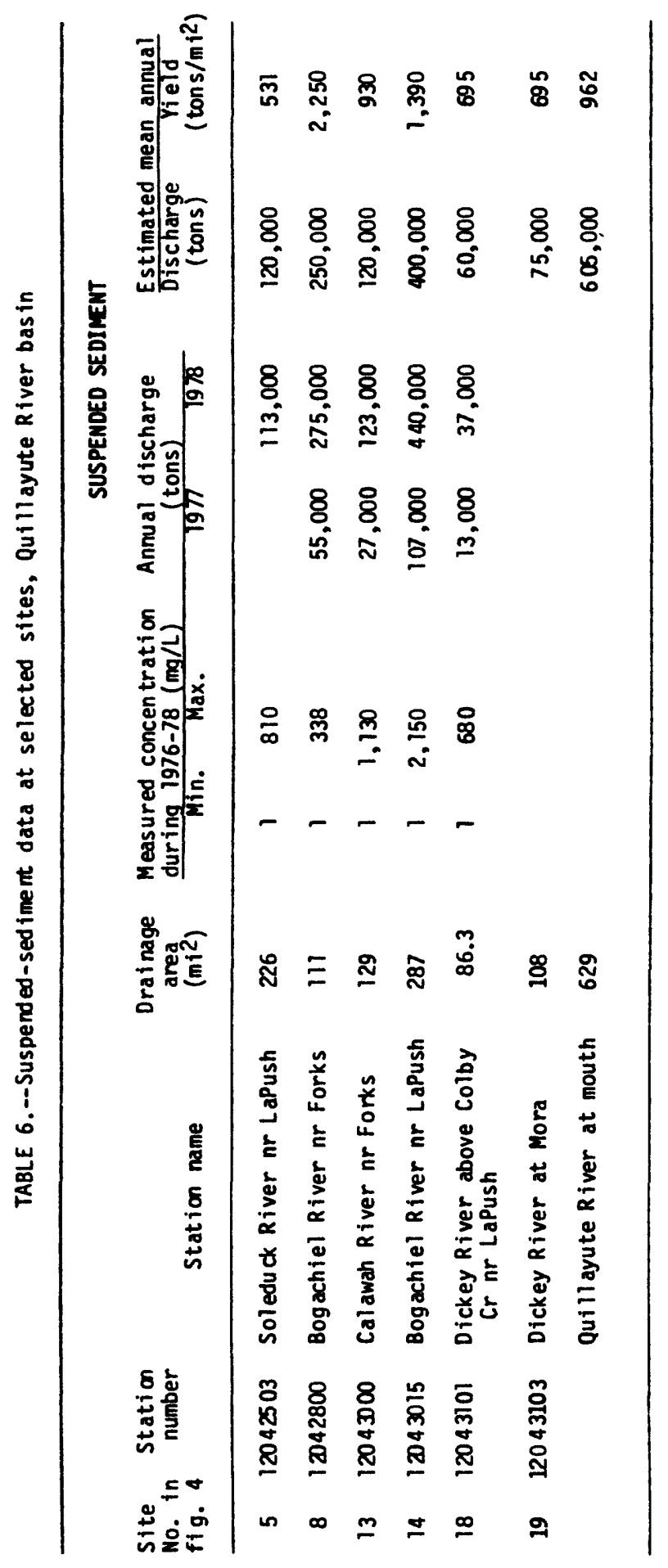




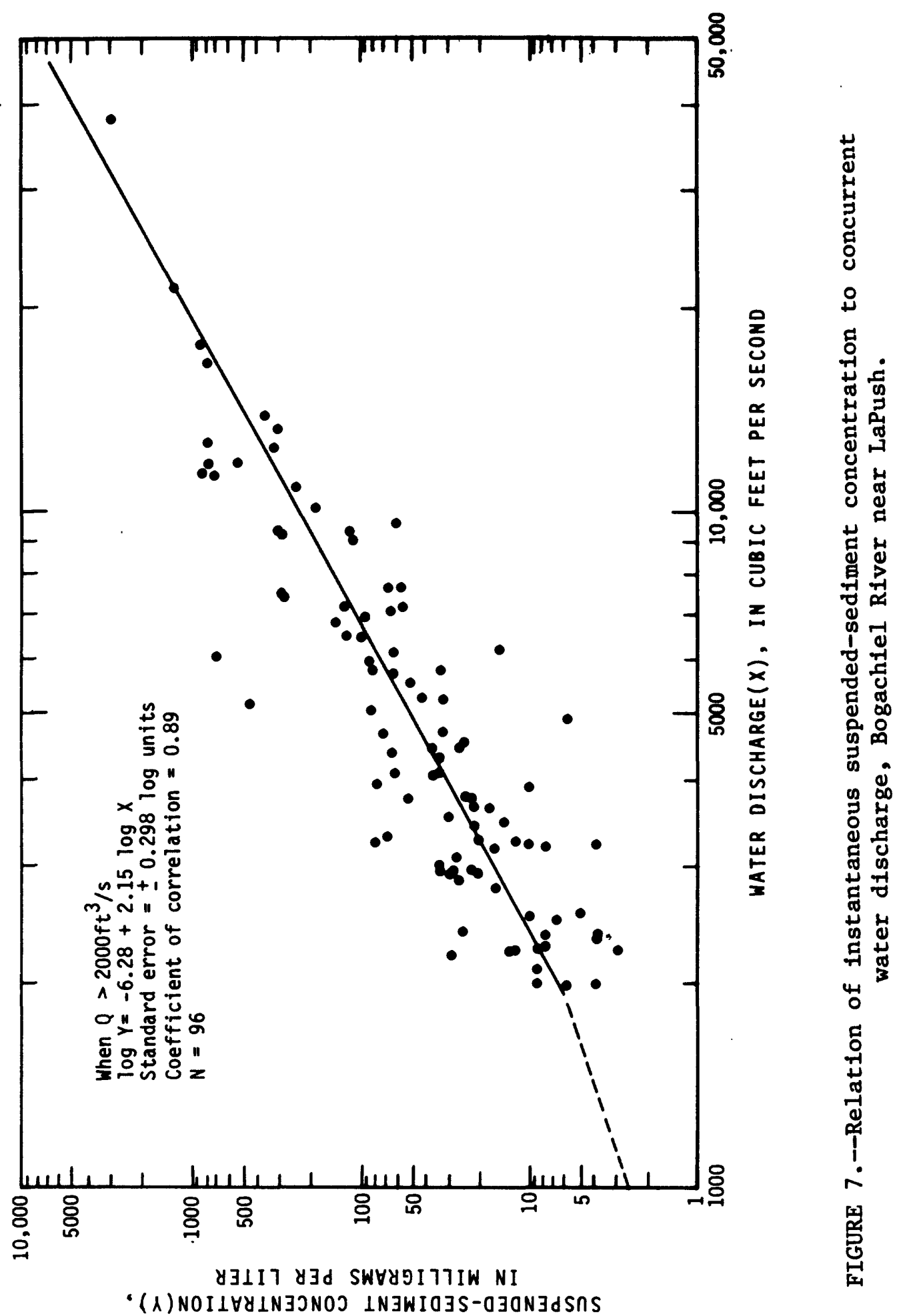




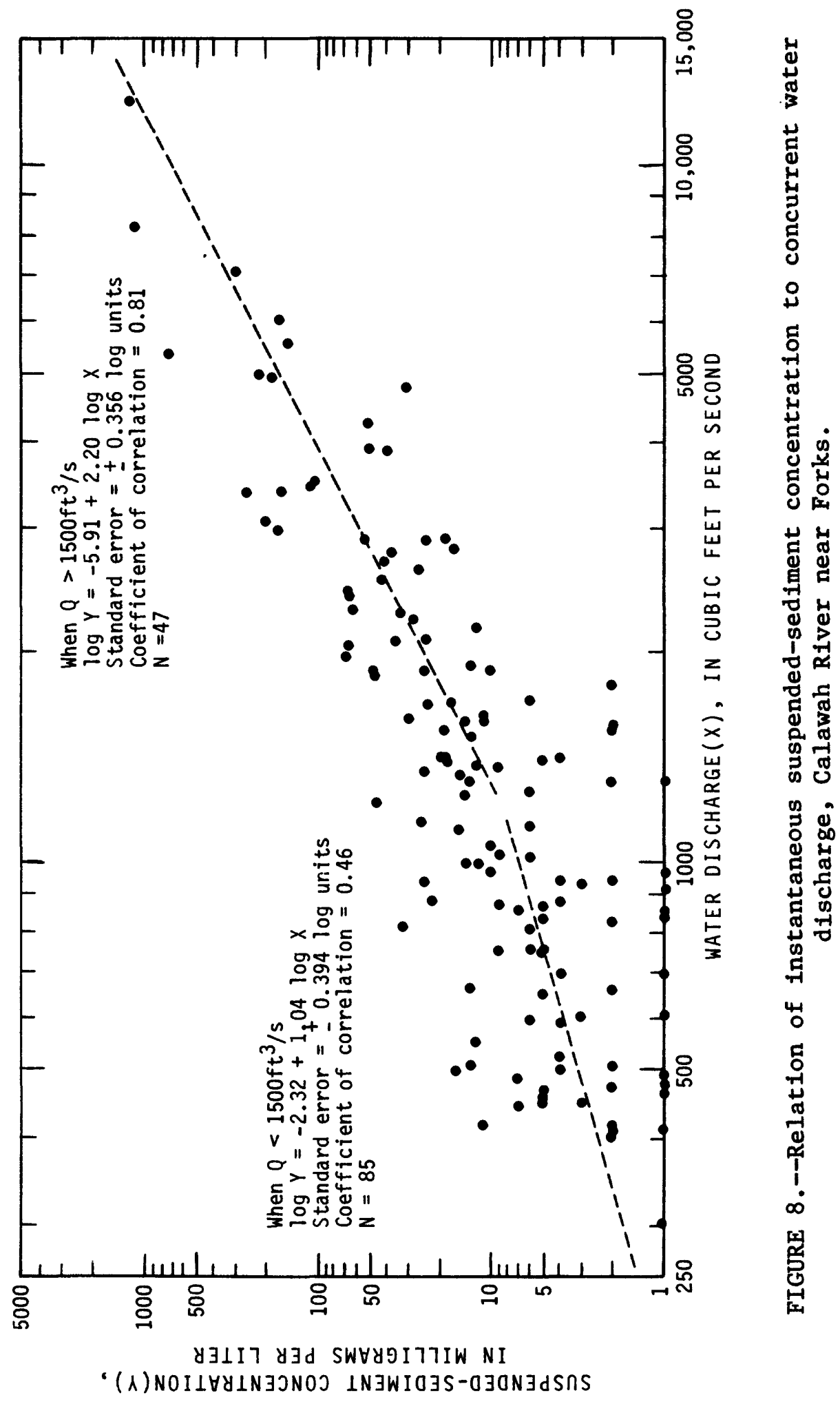




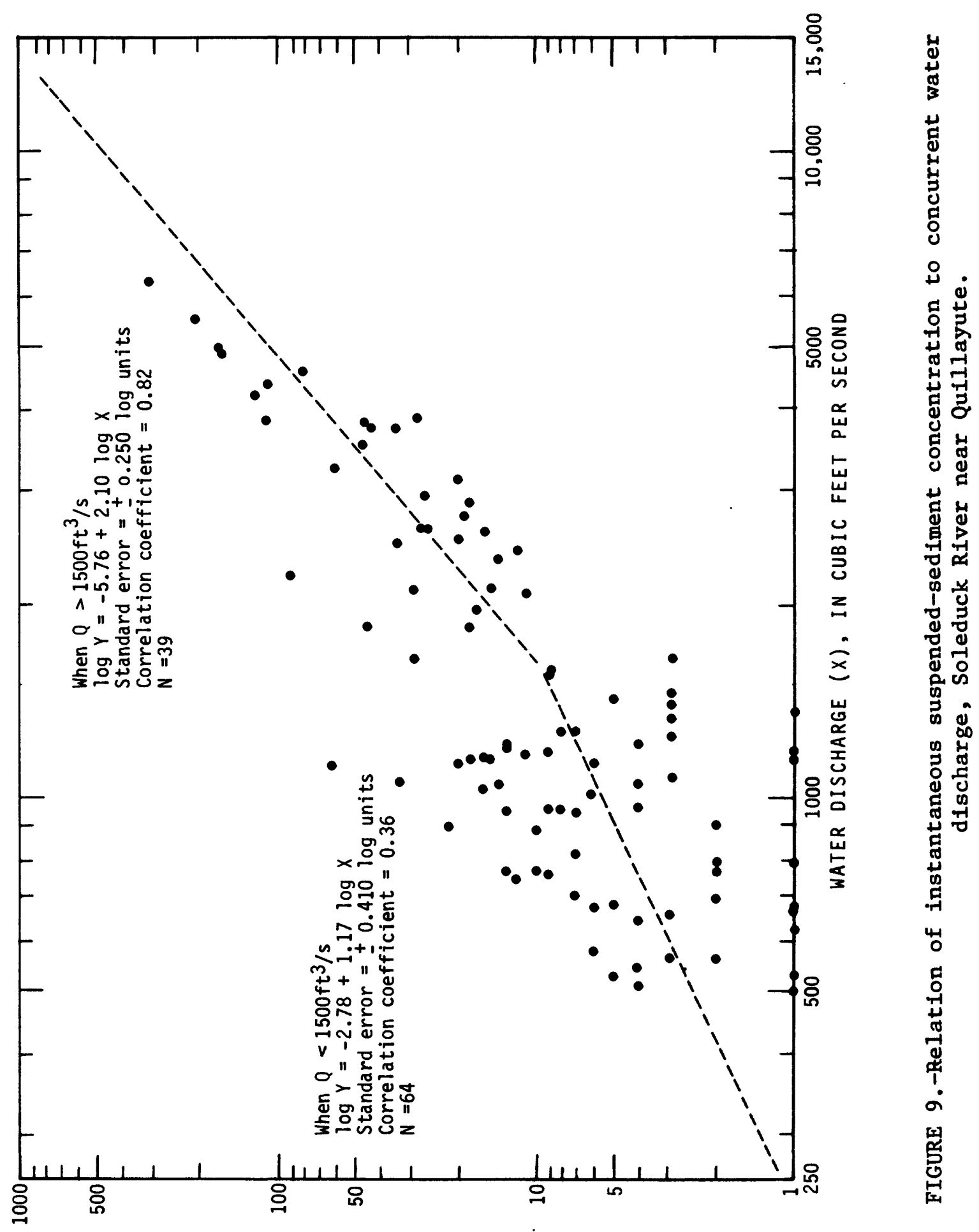

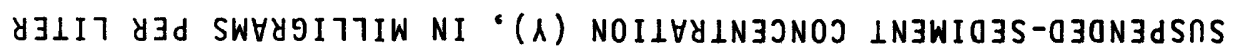




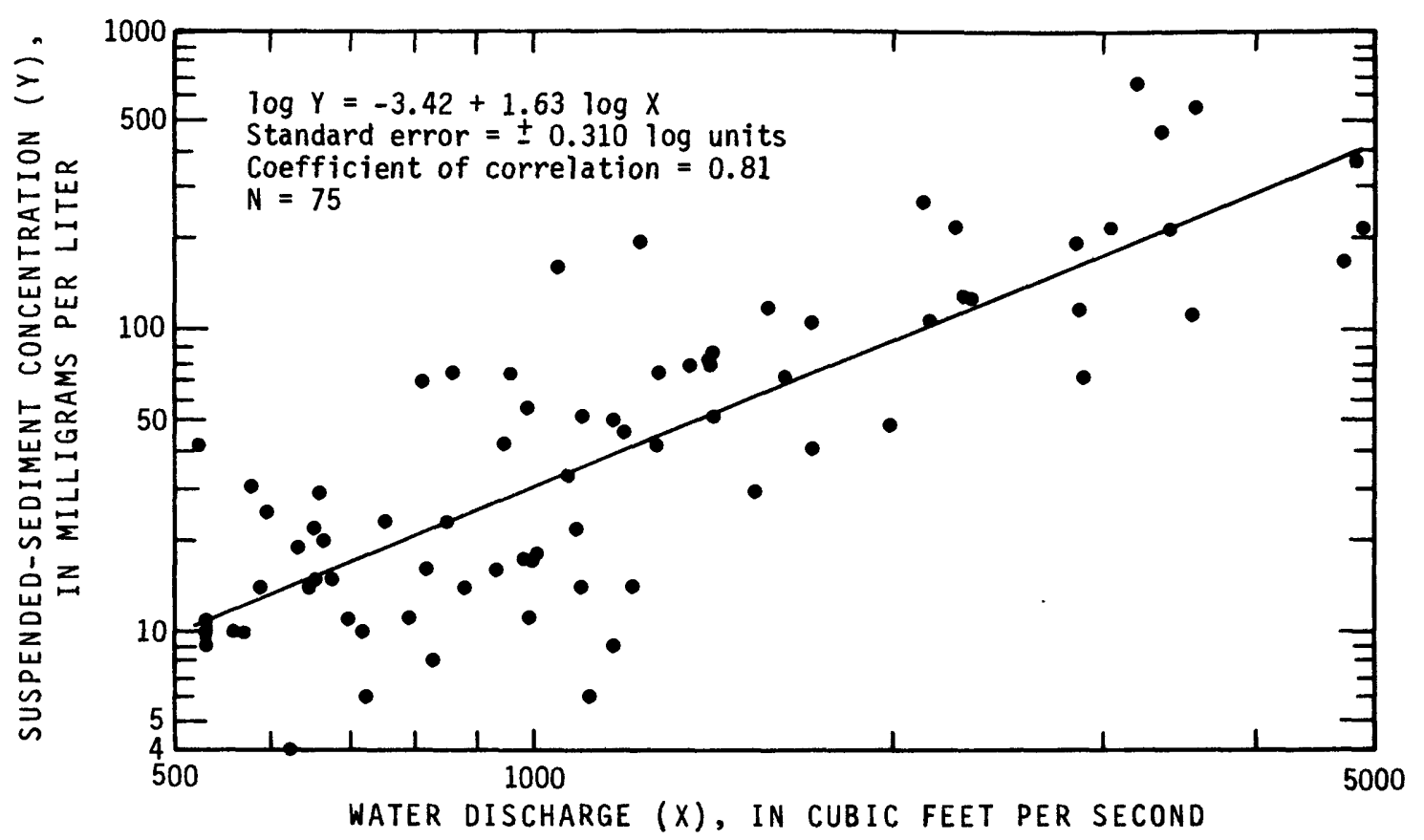

FIGURE 10.--Relation of instantaneous suspended-sediment concentration to concurrent water discharge, Dickey River near LaPush. 
High precipitation provides for rapid recovery of vegetation. This prevents extended erosion from logging and road building. If those activities remain unchanged from their levels during this study, little change in streamflow and sediment transport could be expected from those found during the study. Although the magnitude and intensity of rainfall influence the sediment transport, stream gradient and availability of transportable sediment appear to have the greatest influence on the sediment transport in the Quillayute River basin.

\section{Bedload Transport}

As requested by the U.S. Army Corps of Engineers, the bedload, which is the sediment moving along and in continuous contact with the streambed, was sampled with a Helley-Smith sampler. However, the relation of the actual bedload-transport rate in the stream to the bedload-transport rate measured using that sampler has not been evaluated. Furthermore, the large amounts of debris carried by these streams precluded any accurate or safe method of using the Helley-Smith sampler during freshets. The Helley-Smith sampler used had a 0.2-millimeter mesh screen and entrapped sediment moving within 3 inches of the streambed (Helley and Smith, 1971). The entrapped sediment was analyzed for particle size and weighed to estimate the sediment moving in the 3-inch zone.

Two samples of the bedload were obtained at each of three sites, Dickey River (site 19), Soleduck River (site 4), and Bogachiel River (site 14). Particle size and other sediment data are compiled in table 7. By themselves, the data from these samples are insufficient to estimate the annual bedload transport.

Figure 11 shows the relation of suspended-sediment discharge to bedload transport during 1974-76 at station 12097850 (White River below Clearwater River, near Buckley). Data given in table 7 for the Soleduck and Bogachiel Rivers were plotted in figure 11. The values for the Dickey River were not plotted because the Dickey River is a sand-bed stream and is not similar to the gravel-cobble bed streams, the Soleduck, Bogachiel, and White Rivers. The values for the Soleduck and Bogachiel Rivers fall along the curve for the White River in figure 11 except the value for the Bogachiel River on December 14, which was expected because heavy debris flow prevented a complete sample on that day. Because the data for the Soleduck and Bogachiel Rivers are within one standard error of estimate for the relationship for the White River, the Soleduck and Bogachiel Rivers probably transport bedload equal to about 4 percent of the suspended-sediment discharge, as does the White River (Nelson, 1979). Because of sparseness of data the bedload transport of the Dickey River is not defined, but should be equal to less than 1 percent of the suspended-sediment discharge as described by the data shown in table 7.

On the basis of the above estimates, about 21,000 tons of bedload are transported annually into the Quillayute River by the Dickey, Soleduck, and Bogachiel Rivers. About three-fourths of that bedload comes from the Bogachiel River, and most of the remainder from the Soleduck River. 


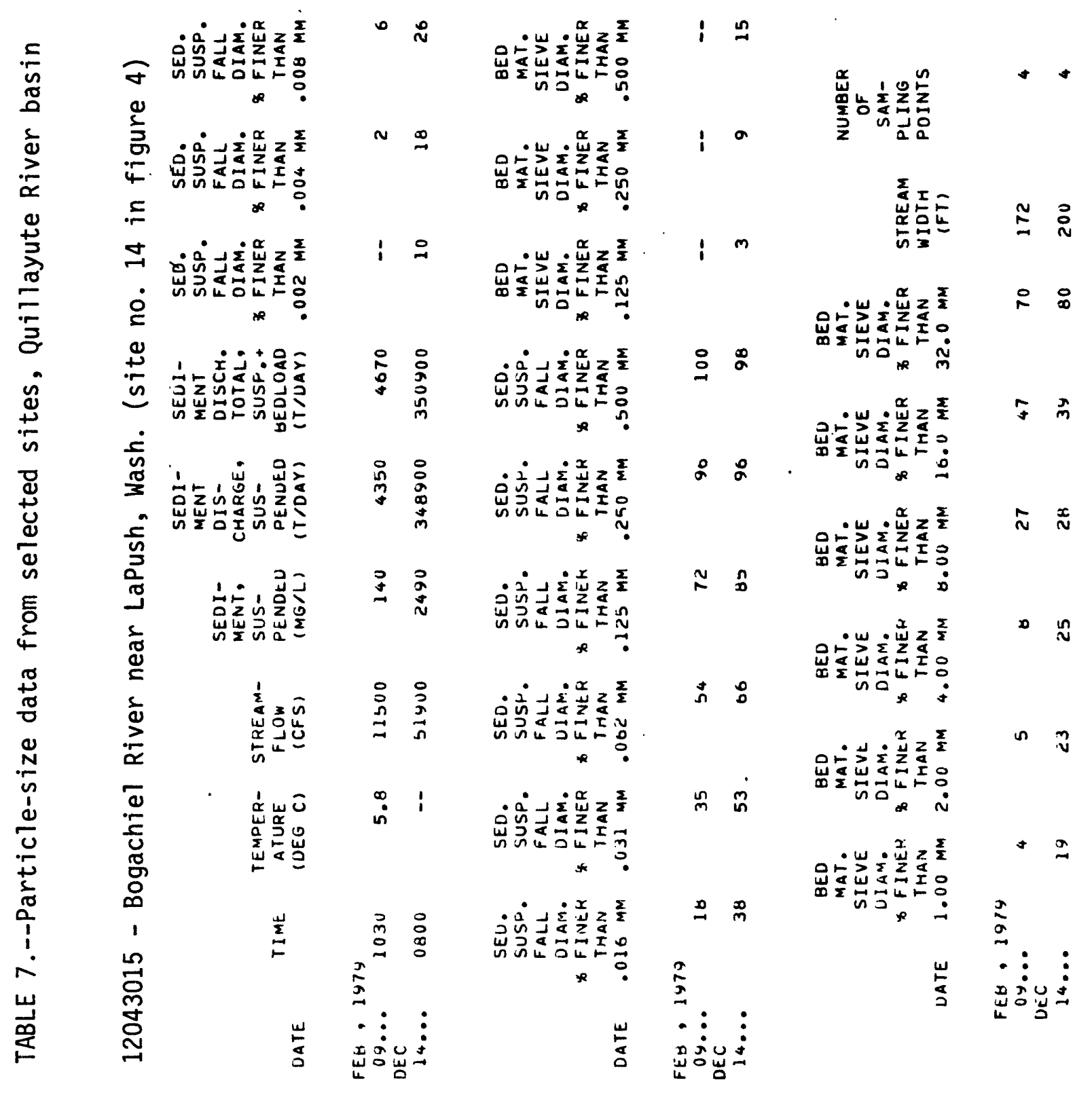




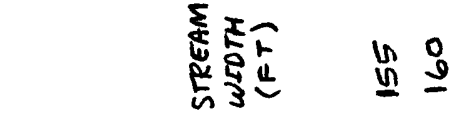

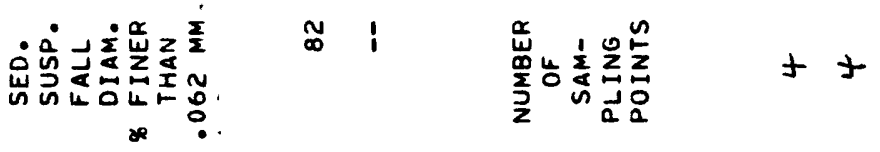

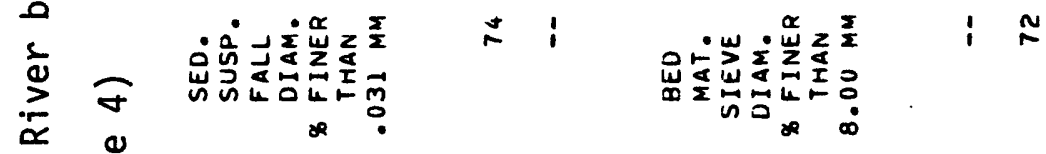

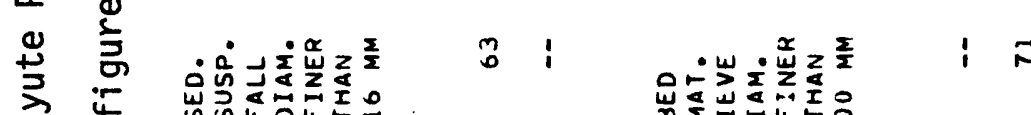
至

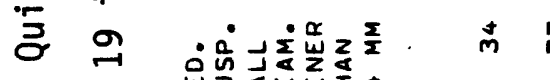

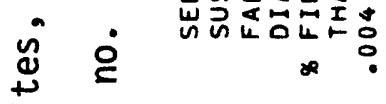

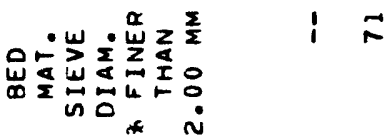

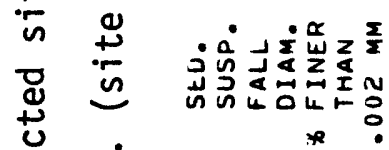

$\frac{0}{\infty} \frac{\dot{0}}{\infty} \frac{\pi}{3}$

E

贲

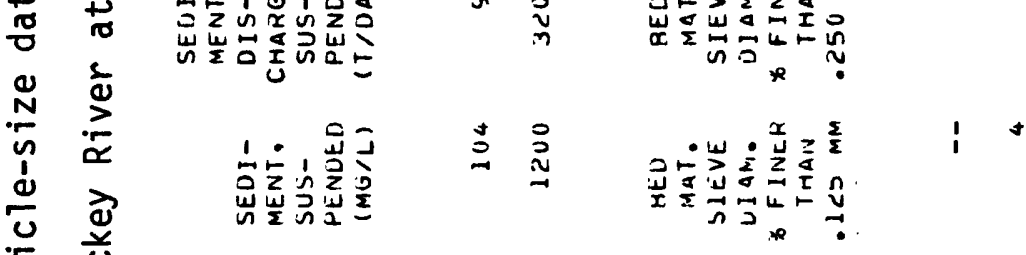

$\because \frac{1}{4}$

!ั

$\therefore$

崫 旁

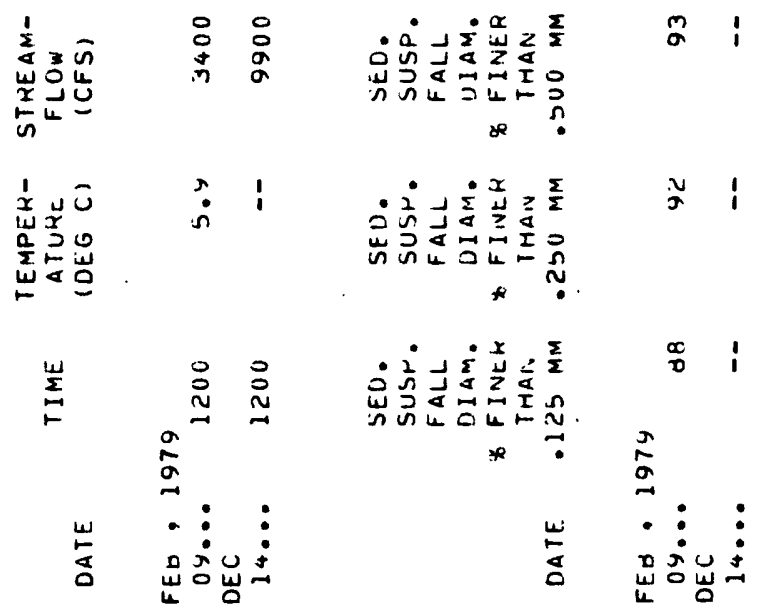




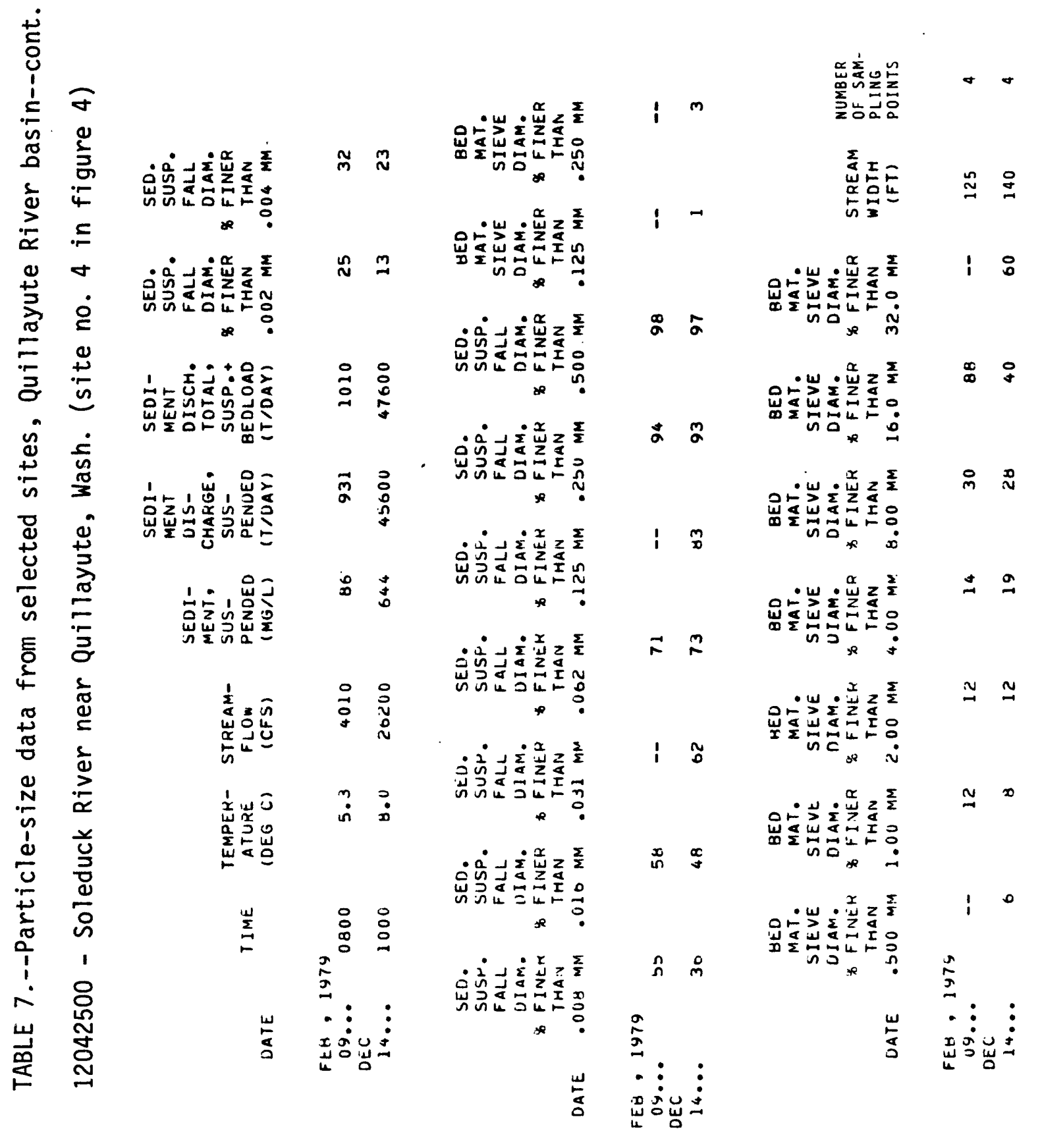




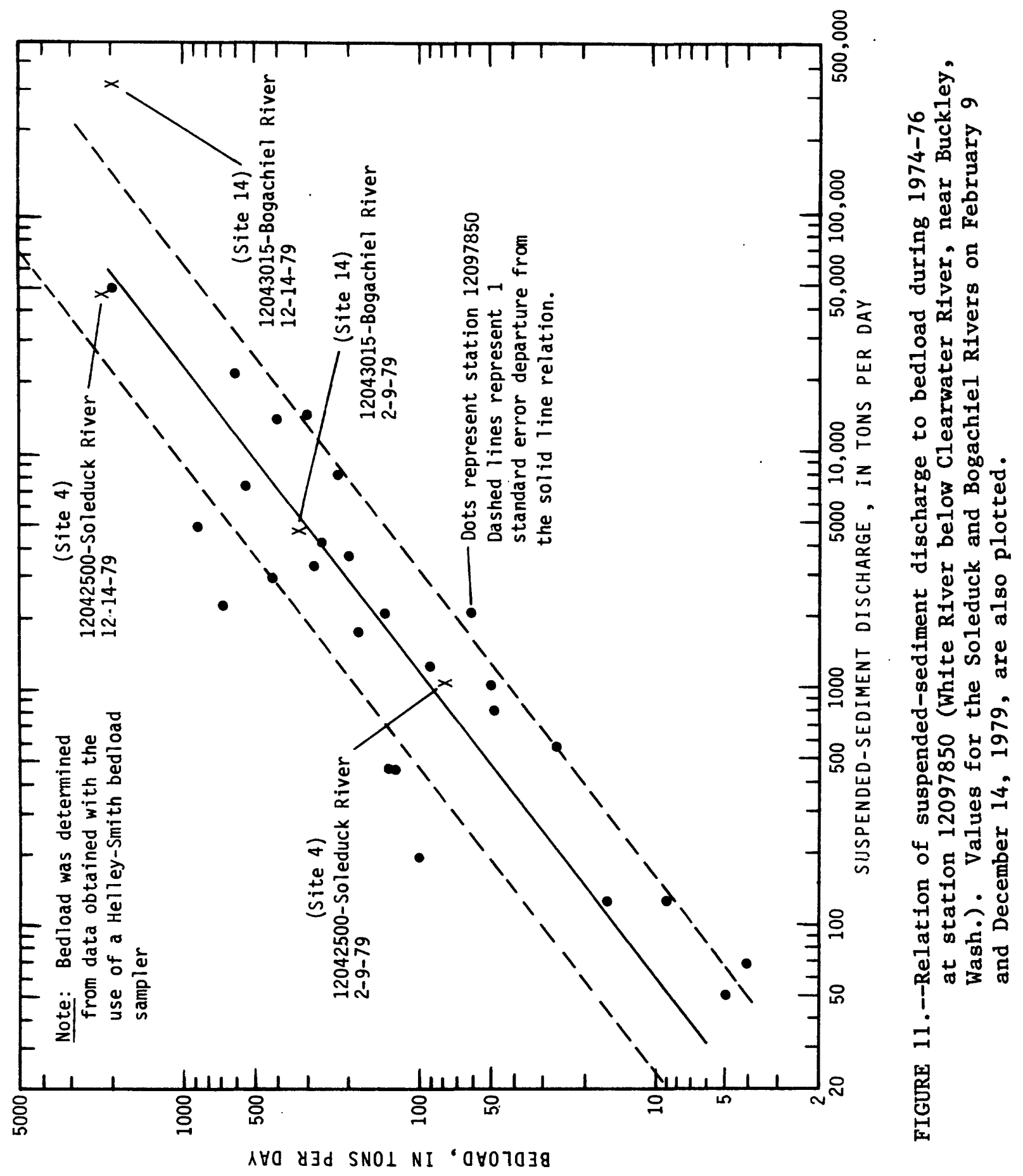




\section{REFERENCES CITED}

Colby, B. R., 1956, Relationship of sediment discharge to streamflow: U.S. Geological Survey Open-File Report, $170 \mathrm{p}$.

Guy, H.P., 1969, Laboratory theory and methods for sediment analysis: U.S. Geological Survey Techniques of Water-Resources Investigations, book 5 , chapter $\mathrm{Cl}, 58 \mathrm{p}$.

Guy, H. P., and Norman, V. W., 1970, Field methods for measurement of fluvial sediment: U.S. Geological Survey Techniques of Water-Resources Investigations, book 3, chapter C2, $59 \mathrm{p}$.

Helley, E. J., and Smith, Winchell, 1971, Development and calibration of a pressure-difference bedload sampler: U.S. Geological Survey Open-File Report, $18 \mathrm{p}$.

Huntting, M.T., Bennett, W. A. G., Livingston, V. E., Jr., and Moen, W. S., 1961, Geologic map of Washington: Washington Division of Mines and Geology, single sheet.

Nelson, L. M., 1970, A method of estimating annual suspended-sediment discharge: in Geological Survey Research, 1970: U.S.Geological Survey Professionat Paper 700-C, p. C233-236.

-1979, Sediment transport by the White River into Mud Mountain Reservoir, Washington, June 1974-June 1976: U.S. Geological Survey Water-Resources Investigations $78-133,26 \mathrm{p}$.

Riggs, H. C. 1972, Low-flow investigations: U.S. Geological Survey Techniques of Water-Resources Investigations, book 4, chapter B2, 20 p.

Smith, L.H., 01sen, H. A., and Fox, W. W., 1951, Soil survey of Clallam County, Washington: U.S. Soil Conservation Service, series 1938, no. 30, 55 p.

Swift, C.H., 1976, Estimation of stream discharges preferred by steelhead trout for spawning and rearing in western Washington: U.S. Geological Survey Open-File Report 75-155, 50 p.

----1979, Preferred stream discharges for salmon spawning and rearing in Washington: U.S. Geological Survey Open-File Report 77-422, 51 p.

U.S. Department of Housing and Urban Development (1980), Flood insurance study, Clallam County, Washington: Federal Insurance Administration, $120 \mathrm{p}$.

U.S. Geological Survey, 1955, 1964, Compilation of records of surface waters of the United States, Part 12: U.S. Geological Survey Water-Supply Papers 1316 and 1736.

-.--1971, 1974, Surface-water supply of the United States, Part 12: U.S. Geological Survey Water-Supply Papers 1932 and 2132.

$-1971-74$, Surface-water records of Washington 1970-74: Tacoma, Washington, annual reports published for years indicated.

1975-79, Water resources for Washington: U.S. Geological Survey Water-Data Reports WA-75-1, WA-76-1, WA-77-1, and WA-78-1. 
U.S. Water Resources Council, 1976, Guidelines for determining flood frequency: Bulletin 17, 26 p. with tables.

U.S. Weather Bureau, 1965, Mean annual precipitation, 1930-1957, State of Washington: Portland, Oregon, U.S. So il Conservation Service, Map M-4430. 